\title{
An electron microscopic study of the tumor blood vessels in oral squamous cell carcinoma, with special reference to the endothelium
}

\author{
Hiroko HARA
}

\begin{abstract}
Tumor blood vessels (TBV) play an important role in the growth of tumors and in cancer therapy. There has been much literature on the vasculature of $\mathrm{TBV}$, but little work on TBV in the human oral region. So the purpose of this study was to clarify the ultrastructure of TBV in human oral squamous cell carcinoma. Conclusions are drawn as follows:

1. Normal blood vessels in oral mucous membrane partially showed endothelial fenestrations with diaphragm (F.D.), but endothelium without F.D. was dominant. The numerical ratio of the former to the latter was about one to four. On the other hand only endothelium without F.D. existed in the blood vessels of tongue muscle.
\end{abstract}

2. In TBV in the untreated cases there were some morphological characteristics.

1) The ratio of the number of endothelium with F.D. to ones without F.D. increased twofold, and discontinuous endothelium (gap) appeared. The gap and F.D. always showed coexistence in the same vessels.

2) Irregular surface, especially numerous luminal processes, characterized the configuration of endothelial cells.

3) Markedly elongated tortuous and dilated junctions were frequent.

4) Two special cell components were observed: Weibel-Palade granules and tubuloreticular inclusions.

The above-described findings, seen mainly in TBV with a diameter of about $20 \mu$, suggested that the permeability of TBV increased considerably.

3. On the other hand, tumor capillaries with a diameter of less than about $8 \mu$ in the untreated cases were composed of plump endothelial cells with low electric density due to sparcity of cell organelles. A number of mesenchymal cells, which surrounded these capillaries, may be related to angiogenesis.

4. After exposure to X-ray with combinations of bleomycin TBV changed ultrastructurally.

In the earlier period, lysosomes and microfilaments in the cytoplasm of the endothelium and irregularity of the nucleus appeared. During the period in which the treatment was completed, the number of lysosomes and microfilaments increased frequently. Furthermore, thrombosis, necrosis of endothelium and destruction of vessels was observed. Namely exposure to $\mathrm{X}$-ray with combinations of bleomycin was presumed to have damaged the endothelium of TBV.

Key words: tumor blood vessels, human oral carcinoma, ultrastructure

九州大学㳡学部口腔外科学第 1 諻座

（主任：田代英雄教授）

First Department of Oral Surgery, Faculty of
Dentistry, Kyushu University (Chief: Prof. Hideo Tashiro)

受付日：昭和 61 年 9 月 16 日 


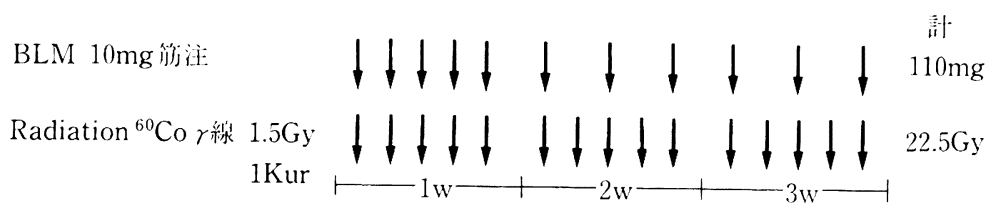

図 1 治療スヶジュール

緒

言

口腔癌の治療に拈いても，外科療法だけでなく，放射 線療法と化学療法が权要な役割りを果たしているが，こ れらの効果を左右する大きな要因の一つに，腫痬を栄養 している血管の状態がある。すなわち，放射線療法の効 果は腫瘍組織の酸素濃度に依存しており ${ }^{1)}$, 化学療法に とっても血行が重要なことはいらまでもない,2,3)

また近年，正常血管と腫痬部血管の形態的および機能 的差異に着目して，アンギオテンシン II ととの投与によ って，腫瘍内血流量を選択的に著明に増加させ，抗癌剂 到達を助長する昇王化学療法が鈴木ら 2 によって開発 され，すでに臨床にも応用されて，優れた治療効果があ ることが報告されている。

そのほか, Folkman ${ }^{4}$ らは, TAF(tumor angiogenesis factor）の拮抗物質の投与によって，腫瘍血管の新生が 抑制され，腫瘍実質細胞が減少することを観察してい る.

このように癌治療において，腫瘍内あるいは腫瘍に流 注する血管は重要な意義をもっているが，口腔癌病変部 の血管についての研究は少なく，わずかに松嶋 ${ }^{5)}$ ，小林 ${ }^{6)}$ の実験舌腫瘍における研究があるだけである。著者は七 ト口腔粘膜扁平上皮癌における腫瘍血管の超微形態を透 過型電子顕微鏡を用いて観察し，その超微形態的特徵を 明らかにし，さらにそれらが放射線照射，Bleomycin 投 与によって，どのような形態変化をするのかを検討し た。

\section{材 料・方 法}

\section{1. 材 料}

A. 正常血管

対照として，埋伏智歯抜去時に採取した臨床的に炎症 所見のない正常被覆粘膜扣よび良性腫瘍摘出時の周囲正 常粘膜を材料とした。採取部位は，舌，煩粘膜，歯肉， 口底部であり，合計30例である。

B，治療前腫瘍血管

治療を開始する直前に癌病巣辺縁を視診, 触診し, 腫 瘍組織と正常組織の境界と判断した線上の数か所に歯科 用リーマを用いて墨汁による入れ墨を行った。この境界
表 1 治療後腫痬血管観察症例の治療内容

\begin{tabular}{c|c|c|c|c}
\hline BLM & $\begin{array}{c}30 \sim 60 \\
(\mathrm{mg})\end{array}$ & $70 \sim 90$ & 110 & $\begin{array}{c}\text { 計 } \\
\text { (例) }\end{array}$ \\
\hline \begin{tabular}{c|c|c|c|}
$(\mathrm{Gy})$ \\
22.5
\end{tabular} & $2(2)$ & 3 & 12 & $17(2)$ \\
27.0 & 1 & 1 & 1 \\
35.1 & 1 & & & 1 \\
\hline 計 & $3(2)$ & 4 & 12 & $19(2)$ \\
\hline
\end{tabular}

( ) : ${ }^{60} \mathrm{Co} 22.5 \mathrm{~Gy}+$ Peplomycin $55 \mathrm{mg}$

線の内側の腫場組織とみなした部位の生検材料を用い た。部位は，舌，歯肉，口唇，口底部とさまざまである。 組織学的には，すべて重層扁平上皮癌であり，合計50例 である。 そのらちわけは, 高分化型33例，中等度分化型 11例，低分化型 6 例である。

C. 治療後腫瘍血管

手術前に図1に示すようなスケジュールに従って合計 ${ }^{60} \mathrm{Co} 22.5 \mathrm{~Gy}$, Bleomycin (以下 BLM) $110 \mathrm{mg}$ を 1 ク ールとして治療を行ったが，各症例によって線量，投薬 量が若干異なっている（表1）。治療終了後，口内炎の 消退を待って（10〜29日後）手術を施行した。その際の 手術摘出材料によるものであり，合計 21 症例である。電 顕標本採取部位は治療開始前の生検時に行ったマーキン グ内の数か所である。なお他施設により $1.5 \mathrm{~Gy} 2$ 回照 射された後の生検標本 2 例も加えた。

治療前, 治療後ともに光顕標本を作製して, 電顕観察 時の参考とした。

\section{2. 透過電顕標本作製法}

いずれの組織も摘出後速やかに Karnovsky 固定液に 浸漬した後，パラフィンワックス上で組織を乾燥させぬ よ5同固定液内で約 $1 \mathrm{~mm}^{3}$ に細切し，氷中で前固定約 $1 \sim 2$ 時間, その後 $2 \%$ カジレート緩衝液で 2 時間洗 浄，ひき続き $1 \%$ オスミウム酸にて後固定を 1 〜 1.5 時 間行った。軽く再度洗浄した後，50\%エタノールから 100\%エタノールヘ段階的に脱水し, エポン 812 に包埋し た. Porter-Blum 型ミクロトームにて厚切り切片を作製 し,トルイジンブルー染色によって観察部位を確認，ガ ラスナイフあるいはダイヤモンドナイフにて超薄切片を 作製した。 ウラン・鉛二重染色をした後，HITACHI H-500にて観察した。 
結

\section{果}

\section{1. 正常口腔粘膜の血管}

対象としたのは，臨床的に炎症所見がない粘膜であ り, 厚切り光顕切片に扎いて，上皮下結合織に炎症性細 胞浸潤がられれい部の血管を観察対象とした。

まず，粘膜上皮下結合織の血管の所見を述べる。観察 した血管の内径は, 約 3 25 $\mu$ で 1 数個の内皮細胞, 内皮細胞を团繞している基底膜，そして周皮細胞が 1 血 管横断面を構成している（写真 1 )。隣接内皮細胞は相 互に, tight junction によって連結しあい，細胞辺縁の 一部が marginal fold として血管腔に突出している場合 もある。核周部の細胞質は厚いが，それ以外の細胞質は 菲薄であり，この部に fenestration がみられることがあ る。以下 fenestration のみられる血管を有空性血管，そ らでない血管を無空性血管とする。

fenestrationは, 中心部がわずか球状に肥厚した隔 膜によって必塞がれており (fenestration with diaphragm 以下 F.D. と略す), この部には明瞭な基底膜 が常に存在している，今回の検索で，有空性血管は観察 した全血管の $22 \%$ である。

F.D. の有無以外飞，有空性血管之無空性血管の形態 学的差異はなかったので以下まとめて記載する。

核は，内皮細胞の形態に注活沿った棈円形であり，核 の不整や切れこみはない 核周囲の細胞質内には，細胞 小器官として少数のミトコンドリア, 粗面小胞体を認め たがゴルジ装置は稀である。直径約 $500 \sim 700 \AA$ の pinocytotic vesicle は，各血管を構成する内皮細胞個々にお。 いてその分布量，分布状態は異なっている。

基底膜は，内皮細胞外周を注注全周において囲繞して いる一層の均質無構造な形態として観察される。一部不 連続な基底膜を有している血管もみられるが，全周にわ たり基底膜が存在しない血管は 1 例むない。

内皮細胞あるいは基底膜の外側には，周皮細胞がほと んどの例で観察される。

舌筋層内の血管形態も基本的には同じであるか，以下 の 3 点が異なる。第 1 と有空性血管はみられず，無空性 血管の々である，第 2 亿直径約 400 3, $000 \AA$ までのさ まざまな大きさの vesicle, vacuole が多数存在している。 第 3 に基底膜は厚く，内皮細胞外側を完全に囲繞してい る(写真 2).

粘膜上皮下結合織内，および笳層内の血管は，血管径 の大きさによる内皮細胞形態，細胞小器官の分布の違い は認められない

\section{2. 治療前腫瘍血管}

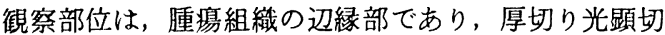
片で腫㻛組織内の血管であることを確認し，壊死部分周 辺の血管，および炎症性細胞浸潤の強い部の血管は対象

\section{より除外した。}

観察した血管の内径は，約 $35 \mu$ までであり有空性， 無空性血管および不連続型血管がみられる。便宜上， Rhodin (1978) 》ののサギ皮虞の venous drainage system の形態学的分類を参考にして，血管内径約 $8 \mu$ 以下を毛 細血管，約 $8 \mu$ 以上を細血管としたところ，両者に形態 学的差異が認められたため，分けて記载する。

\section{A. 毛細血管}

腫痬毛細血管は，有空性と無空性の 2 つのタイプがみ られ，不連続型血管は認められない。

血管横断面において，血管壁は 1 〜数個の内皮細胞よ りなり，内皮細胞の一部の細胞質が著しく厚く，血管壁 を狭窄しているものがほとんどである，内皮細胞は，中 等度電子密度を有しているものと, 著しく電子密度の低 いものの 2 種が観察されるが，中等度電子密度を有して いる内皮細胞は細胞質が厚い以外には，正常毛細血管と は差違がない。

電子密度の低い内皮細胞には, 通常の電子密度の内皮 細胞と比較すると, 形態学的にも差異が認められる（写 真 3，4)。市核自体も電子密度が低く核膜周囲にへ テロクロマチンがわずかに認められるのみである。 ミト コンドリアは小さく，クリステが少なく，ほとんどクリ ステがみられないこともある。粗面小胞体は泡洙状で, 内部はやや拡張，リボゾームの付着も不規則で少なく， ゴルジ装置は全く認めない，遊離りボゾームは少なくロ ゼット状に集簇し，散在するのみである。 pinocytotic vesicle も非常に少ない隣接する内皮細胞間には，tight junction を認めるかi, junction 部の㕍開はない.

基底膜は全体的に肥厚し，厚さは部位により異なり， 周囲結合織部の基質と区別がつかないこともある.

周皮細胞は全例存在し, 細胞質は韭薄で, 細胞内小器 官, pinocytotic vesicle は少ない、

これらの内皮細胞よりなる非常に小さな血管（外径的 $4 \mu$ 以内)の周罚には,必ず多くの間葉系細胞が存在して いる。すなわち，紡錐形で細長い細胞質を有する粗面小 胞体の豊富な線維芽細胞（写真了）， あるいは細胞外形 は不整で，同定が困難な間葉系細胞がシート状に多数集 合しこの血管を围繞している，またリンパ球，形質細胞 などの炎症性細胞も認められる(写真 4).

\section{B. 細血管}

内径 $8 \mu$ 以上の血管横断面では, 内皮細胞は 3 個以上 よりなり，その形態はきわめて多様性に富さ超微構造を 呈し，連続型血管のみならず，不連続型の血管もみられ る.

\section{1) 連絖型血管}

有空性と無空性であり，有空性血管は全観察血管の40 \%を示した，有空性血管では F.D. が 1 内皮細胞 1 切片 に 1 〜数個存在し内皮細胞によっては，連続して多数み られることもある. 
無空性血管も，F.D. の有無以外には基本的に有空性 と形態的に差異を認めない。また，ほとんど正常血管と 区別のつかない形態を呈している血管もあったが，正常 血管では観察されなかった特徽的所見が得られた。すな わち多数の血管腔側の突起 (写真 5,6 ), junction の 形態異常（写真 7, 8) および特異な細胞小器官の存在 である（写真 $9,10,11 ）$.

腫湯血管の内皮細胞の形態は，不整であり，また血管 腔側および基底膜側表面も不規則で，大小長短さまざま の突起を認める. 特に血管腔側の突起は luminal process (1970. Long ${ }^{\text {9) }}$ ) とよばれ, 長さ $2 \mu$ に及ぶものもある. luminal process 内には, 細胞小器官は全く認められず, 細胞基質のみである。このうち長い触手様のものは単に 血管腔側へ突出しているだけでなくループ状となって， vacuole を形成したり， luminal process 内に F.D.を 認める場合もある（写真 6 ).

多数の長い luminal process の存在する内皮細胞は marginal fold む同様に長く, pinocytotic vesicle, vacuole の数も多い(写真 5,6 ). しかし，ミトコンドリ ア, 粗面小胞体などの細胞小器官の形態, 分布には特徵 的な所見は認められない

次に junction の異常形態とは, junction 部が非常に 長い距離にわたり，屈曲し，らずまき状を呈していた

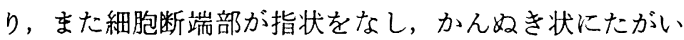
に入りこんでいるもの，あるいは junction 内で一方の 細胞質にF.D. を認めるものなど（写真 7)，各血管，各 内皮細胞において非常に多様な像を呈している。最も多 くみられる junction の形態は, junctional structure が 数個所に認められるものの, 隣接内皮細胞形質膜間の距 離が数千 凡と離開している像である（写真 8 ）.

前記した形態上の相違の他に，正常血管内皮細胞には 認められない特異な細胞構成要素も2 種類観察される.

一つは, Weibel-Palade 顆粒 (以下 W-P body と略 す）である。これは，棍棒状で長さ約 $0.3 \sim 1.0 \mu$ で， 幅が約 $0.1 \sim 0.3 \mu$ であり，一層の限界膜で囲まれた中 等度の電子密度を有する構造物で, 内部には数個の微細 管が長軸に沿って平行に配列している，存在様式に，一 定の方向性, 規則性がなく, 大部分は核の周辺部に存在 する (写真 9)。 まれに細胞質の比較的薄い部にも見ら れることもある，核周部に発達したゴルジ装置内に，数 個の W-P body が集合し，一部ゴルジ装置内の cisterna および vesicle と連続している像もみられるが(写真 9), 多くの例では, 特に細胞小器官との関連は認め得ない. W-P body は, 腫瘍毛細血管内皮細胞にも認められる が，出現頻度は，径の大きな細血管の方が高く，その数 は細血管で 1 内皮細胞 1 切片当り $1 \sim 7$ 個, 平均 3 個, 毛細血管で 1 〜 個，平均 1.5 個である.

もら一つの特異な構成要素は tubulo-reticular-inclusions (TRI) である（写真 10，11）。これは，電子密度
の高いさまざまな長さの波状にらねった tubule（径約 $200 \AA$ ）が互いに絡みあい，網状に集合した檴造物であ る。集塊の大きさは一様ではなく, 最小 $0.3 \sim 0.4 \mu$, 最 大 $0.9 \sim 0.8 \mu$ で，限界膜の存在も一定しない。集塊内 の tubule は非常に密に集合して一見ふるいを思わせる 型のもの（写真11）と, tubule の集合が蹯である型（写 真10）の 2 種類が認められる。ふるい型のものは，明瞭 な限界膜を有し，集塊としては大型であるが，出現率は 低い。

TRI の多くは，核周辺に出現し，1内皮細胞 1 切片当 り 1 〜 個である。また，その半数以上は，非常に払張 した粗面小胞体内に存在しているが（写真 10), 粗面小 胞体および他の細胞小器官との関連は明らかではないも のもある (写真 11). このうち拡張した粗面小胞体内に 存在する場合には, 大半は粗面小胞体膜との連続性がみ られる。

腫瘍細血管だけでなく腫瘍毛細血管にも TRI はみら れたが，出現頻度は低く，また電子密度の低い毛細血管 内皮細胞ではほとんどみられない，また今回の検索で は，1例のみ血管周囲の間葉系の細胞にも TRI を認め たが，腫瘍細胞の細胞質には全く観察しえなかった。

基底膜は，各血管および各内皮細胞によりさまざまな 状態を呈している。すなわち内皮細胞全周を一層で囲繞 しているが, 部位によっては一部消失, 肥厚あるいは多 層化がみられ，また均質無構造な物質が厚く囲み，周囲 結合織基質との区別が困難なため, 基底膜として判別し 難い場合などがある。

その他, 核, ミトコンドリア、粗面小胞体などの細胞 小器官については全く特徽的な所見はなく, pinocytotic vesicle の分布量, 分布状態も各血管, 各内皮細胞で異 なり一定の傾向は認め得ない.

\section{2 ) 不連続型血管}

不連続型の内皮細胞は, すべて有空性内皮細胞に接続 しており, gap の大きさは約 $0.16 〜 0.75 \mu$ に及ぶ. gap の存在部位は, 菲薄な細胞質であり, junction 部にごく 近接してみられることが多い（写真 12）。 また不連続部 断端の形質膜は明瞭であり，電子密度が高くなっている などの所見は認められない. gap 部には基底膜を認め ず，不連続部に赤血球の細胞質の一部が嵌入している 像, 扰よび血管腔内に内皮細胞断端之思われる細胞質が 翻転, 残存している像もみられる (写真13).

\section{3. 治療後腫瘍血管について}

手術摘出標本において, 治療前に行った入墨によるマ 一キング内の数か所より採取した電䫓用のブロックを, まず厚切り光顕切片にて検鏡した，次いで腫瘍細胞の生 存状況による血管形態の差異の有無を明らかにするため 大星らの分類”)を参考にして 3 群，すなわち

1 群：生活癌細胞残存部の血管

2 群: 癌細胞が変性, 異物多核巨細胞が出現している 
部の血管

3 群 : 完全に癌細胞が消失して結合組織に置換されて いる部の血管

に分けた結果， 2 群と 3 群では差が認められず， 1 群と 両群の間に明らかな差が認められた。

\section{A. 1 群の血管}

観察した血管の内径は約 $40 \mu$ までで，有空性，無空 性の連続型血管と不連続型血管が認められた。有空性血 管の存在率は, 観察した全血管数の13\%であり, 治療前 腫瘍血管の比率より低下していた，治療後においても治 療前同様，毛細血管と細血管では形態が異なっていたの で分けて記载する。

1) 毛細血管

毛細血管には，不連続型血管は認めない，血管腔は狭 窄してスリット状になっているか，そらでなければ血管 腔内に赤血球を入れている。

内皮細胞は，治療前の腫瘍血管と同しく，正常毛細血 管と同様の電子密度を有するものと電子密度の低下して いるものの 2 種が認められ, 電子密度の低い内皮細胞は 細胞小器官が極端に少なく, 核の電子密度も低くなって いる。

中等度電子密度の内皮細胞は，二核を思わせる分葉核 など核形態が著しく不整で，核膜の切れ込みが強くみら れる。核小体は円形ないしは楕円形で，核質に比較し大 きく腫大している，核小体の形態は，電子密度の高い部 と低い部が絡みあって網目状を呈するものと，高電子密 度の基質内に低電子密度の部が円形をなして数個散在し ている 2 型がみられるが，核小体の分離の所見はない。

2 ）細血管

連続型有空性，無空性および不連続型の血管がみら れ，ほとんどの血管腔には赤血球，血小板，フィブリン などの血液成分が観察された。

血管腔側拉よび基底膜側ともに不整でさまざまな偽 足, 突起がみられ, 治療前と同様の多くの luminal process, W-P body，TRI を有する内皮細胞を認める。 そ してその他に正常および治療前にみられない特徵的な所 見，すなわち核の形態異常，マイクロフィラメント，ラ イソゾームの出現，内皮細胞の壊死が観察される.

核の形態は著しく不整で，内皮細胞の形態の不整と共 に，砂時計様に中央でくびれた核（写真14）をはじめと して, 核膜の切れこみが顕著で核質の電子密度は低下し ている (写真15).

正常および治療前腫瘍血管内皮細胞にも，マイクロフ ィラメントをまれに認めることがあるが，治療後の多く の血管ではさらに明膫である (写真 16)。 マイクロフィ ラメントは，細胞質内に均等に分布しているわけではな

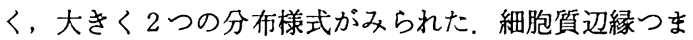
り形質膜に沿って，一定の方向に密に配列している型 と、細胞質内でまったく規則性をもたず柾に散在してい
る型である．1つの内皮細胞で両方の分布様式をとって いるものもあるが，多くは，後者のみで，ミトコンドリ アなどの細胞小器官の間を縫うようにさまざまな方向に 走行している (写真16).

治療後の血管内皮細胞のも51つの特改はライッゾー ムの出現である（写真17，18）ライソゾームはほぽ円形 で， 1 層の限界膜に囲まれている，そのらち中等度の電 子密度で内部が均質無構造のもの, 内部が不均質で大小 様々の vesicle を有するもの, まったくの空胞で一部高 電子密度の構造を有するもの，ミエリン様構造を呈する ものなど，その形態は実に多彩である。また，核周辺の 細胞質内に，1 層の限界膜に囲まれた大きな円形のラ1 ソゾームが存在する場合むある（写真 18）。その限界膜 は一部不明瞭で, 内部は不均質, 電子密度のやや低い基 質と，大小の空胞よりなっている。 大きな空胞は，その 大きさと内部構造よりミトコンドリアの変性物と思わ れ，これはオートファゴライソゾームと推定される。

不連続型血管は治療前の不連続型血管と同様に，必ず 有空性内皮細胞に接続する。 gap は, 細胞質の菲薄な部 のみでなく，核近傍の厚い細胞質にもみられるが，治療 前腫場血管のそれと形態的に差はなく，gap 断端の形質 膜は明膫であり, 基底膜も認めない。

不連続型血管にみられる最も異常な形態は内皮細胞の 懐死である（写真19，20）。すなわち内皮細胞は菲薄で, 電子密度が高く, 細胞小器官はほとんどなく, 大小さま ざまの空胞が多数存在する。この空胞には限界膜が明瞭 なものとそうでないものがあり，変性したミトコンドり フと思われる構造物も認める。このように内皮細胞が壊 死性变化を呈している血管では，基底膜が同心円状に多 層化している像を観察することが多い（写真19）。

壊死を起こした内皮細胞の gap 部には必ず血栓を認め る（写真 19，20）。血管腔は完全に血小板，フィブリン で閉塞され，さらに血管周囲腔にまでこれら血液成分が およんでいる部の内皮細胞は形質膜が不明膫で，細胞質 の変性が著しく，ところどころで内皮細胞の断裂を認め る(写真20).

わずか 2 例ではあるが， $1.5 \mathrm{~Gy} 2$ 回分割照射後の生 検標本に批ける血管内皮細胞には，ライソゾーム，マイ クロフィラメントの出現，核の不整の所見が既にある. 血管腔内には, 赤血球, 血小板が充満しているが, フィ ブリンは認めず，壊死性変化を呈している血管内皮細胞 も認めない。

B． 2 扰よび 3 群の血管

腫湯細胞が变性, 消失し, 異物多核巨細胞が認められ たり，結合組織に完全に置換されている間質部の血管に は，1群で観察された多彩な超微形態像はない，毛細血 管，細血管ともに有空性，無空性の 2 種のみを認め，有 空性血管の存在率は全血管数の $10 \%$ であり，径の違いに よる血管形態の差異はない. 
正常血管と異なる形態は，血管腔の狭窄およびコルシ 装置が発達している点, ミトコンドリアの腫脹, クリス テの消失, 粗面小胞体の扗張であるが, 大部分の内皮細 胞は，正常血管とほとんど差がない。

\section{考察}

\section{1. 治療前腫瘍血管}

腫瘍血管とは，山浦 ${ }^{10)}$ が (1) 腫瘍の栄羔血管であり, （2）腫瘍細胞に近接して存在し，（3）腫瘍細胞の影響に より腫瘍独自の変化を受けている血管であると定義して いる。また, 鈴木ら ${ }^{11)}$ は, 腫瘍血管とは, 固有間質とし ての血管，すなわち宿主の血管から新たに誘導された新 生血管を指すが, 癌の増殖に伴って癌組織の中にとりこ まれた既存の偶然間質としての血管も腫瘍血管化してい くため双方とも合わせ広義の腫瘍血管とみなすことが可 能であると述べている.

著者はこれらの定義に基ついて腫瘍血管の観察を行っ た.ここでいら腫瘍血管とは腫瘍辺縁部の, 増殖先端部 と考えられる部での腫瘍塊内の血管であり, これについ て超微形態的に観察を行い, 正常粘膜血管と比較するこ とにより，ヒトロ腔扁平上皮癌における腫瘍血管の超微 形態学的特徵を明らかにした。 また，他の腫瘍における 腫瘍血管との相違，腫瘍血管の物質透過性，および腫湟 血管新生について考察を加えた。
A. 腫瘍血管の超微形態学的特徵
1）血管型

Bennet ら ${ }^{12)}$ は，毛細血管を 7 型に分類しているが, 一般的には連続型無空性, 連続型有空性, 不連続型血管 の 3 型に分類している ${ }^{13 \sim 16)}$ 本研究の治療前腫瘍血管で は 3 型とも認めた.

(1) 有空性血管

有空性血管の存在率は，正常血管では $22 \%$ ，腫瘍血管 では40\%と有意に多い結果が得られた。高橋ら ${ }^{17)} は$ ，歯 肉内縁上皮に有意に有空性血管が多いことを，浸出液の 流出といら特異な機能に結びつけ rapid transfer に都合 のよい形態的所見であると述べており，有空性血管の存 在率の高さは物質透過性の高さを示す所見であると考え た.

ヒトロ腔扁平上皮癌において, 本来有空性血管を認め ない舌筋部に浸潤した腫瘍内の血管に，有空性血管を多 数認めたことにより，有空性血管は扁平上皮癌腫瘍血管 の一形態であると考えた。

(2) 不連続型血管

辻本 ${ }^{18)}$, Vick ら ${ }^{19)}$ は, gap を形成している腫瘍血管 内皮細胞断端部に junctional structure を有すといら明 らかな所見が認められなかったとして intraendothelial gap であると述べている. しかし, Papadimitriou ${ }^{20)}$, Seng ${ }^{21)}$ は, sinusoid 血管, あるいは open cell junction
の表現を使い interendothelial gap と解釈しているが， junction の開大であるといら根拠は明確にしていない. このように超薄切片では三次元的な解釈が困難であるた め, 内皮細胞細胞質内にみられる隔膜を有さない間隙を 単に gap と呼び, その血管を不連続型血管としている ようである ${ }^{1821)}$. 著者の観察では, gap は junctionの 近傍でみられることが多いが， junction と連続する所 見はなく, gap 断端の形質膜には junctional structure を明らかに認めていないため, intraendothelial gap で あると考えた。しかしここの点を明らかにするにはさら に走査型電影での微察が必要であろう。

腫瘍血管内皮細胞における gap の大きさは, 報告者

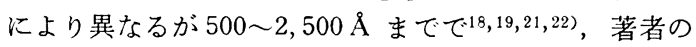
観察した $1,600 〜 7,500 \AA$ は従来の報告よりかなり大き く，また全例基底膜が存在していないことより物質透過 珄の六進に果たす役割りは大きいと推測される。

また，必ず同一血管において gap と F.D. を認めた ことより，骨髄静脈洞壁において坂井 ${ }^{23}$ も述べているよ らに F.D. と gap の形成起源には関連があるのではな いかと推測した。

2) 内皮細胞の形態

腫瘍血管に特徵的な所見である luminal process と junction の形態異常について述べる.

(1) Luminal process について

腫瘍血管内皮細胞の血管腔は平滑でなく多数の指状, 紐状の突起が存在することが多く, 特に多数の長い luminal process について, Seng ${ }^{20,24)}$, 松嶋 ${ }^{5)}$, Long ${ }^{8)}$ の 報告がある. Seng ${ }^{20,24)}$ は，長さ $6 \mu$ にもおよぶ luminal process を低分化型肺癌に認め, 物質輸送能力を高めて いる所見と推測している.

著者は, 有空性血管のみに多数の luminal process 認め，また同じ血管に，発達した marginal fold および 多数の pinocytotic vesicle, vacuole を観察した. luminal process の先端はループ状を呈し, あたかも vacuole を形成しているかの所見もあり，物質輸送との関連が示 唆された。 しかし低分化型のみにみられるとは限らず, 組織型との関連はないようであった。

(2) Junction

長い経路にわたってねじまがったり，入り組えたりす る junctionの形態の不規則性および junction の開大を

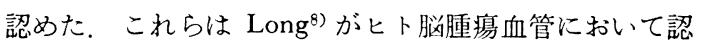
めた所見と同様であり，両所見とも脳腫瘍にお゙ける脳血 液関門の破綻の原因たと推测している。

junction の経路の異常は, 切片の切れ方にもよるであ ろらが，内皮細胞の構築の不規則性を示す所見であろら と思われる。また細胞間の開大といっても必ず数か所は 形質膜の瘉合がみられ，これも透過性の交進を示哱する 所見とは言いがたい.しかし正常の junction に比して 血管壁の脆弱さを表す形態であり，何らかの刺激により 
表 2 各種覀性腫瘍腫湟血管血管の超微形態的特徵

\begin{tabular}{|c|c|c|c|c|c|c|c|}
\hline & gap & F.D. & $\begin{array}{l}\text { luminal } \\
\text { process }\end{array}$ & $\begin{array}{l}\text { junction } \\
\text { の異常 }\end{array}$ & $\begin{array}{l}\text { 基底膜の } \\
\text { 異常 }\end{array}$ & TRI & W-P body \\
\hline ヒト肺癌20) & + & + & + & & & & \\
\hline ヒト甲状腺癌40) & & + & & & + & & \\
\hline ヒト婜性黑色腫 ${ }^{39)}$ & & + & & & + & & \\
\hline ヒト脳腫㾇26) & & + & & & & + & + \\
\hline ヒト脳腫浣 ${ }^{8)}$ & + & + & + & + & & & \\
\hline ヒト肝癌 ${ }^{37)}$ & + & + & & + & & & \\
\hline ヒトロ腔癌(著者) & + & + & + & + & & + & + \\
\hline
\end{tabular}

容易に junction の開大, 透過性の充進が起こる状態で あろらと推測される。

(3) 細胞小器官

看瘍血管においては, 特異な紐胞小器官である, W-P body と TRI を認めた.

W-P body は, 1964年 Weibel と Palade ${ }^{25)}$ がヒト。 ラット，両棲類の小動脈の血管内皮細胞で観察して以 来, 種々の動物, 臓器の血管内皮細胞に認められてい $3^{26 \sim 28)}$

$\mathrm{Hirano}^{26)}$ ，Kumar ${ }^{27)}$ は腫瘍血管において出現率が高 いことを報告している，Kumar ${ }^{27)}$ は，W-P body が血 管新生に関与し, active に增生する毛細血管の指標とな り，またその数が内皮細胞分化の指標となると述べてい る. 著者の観察においても正常血管では舌筋部の血管の ごく一部に認めた程度であるが, 腫瘍血管では平均 3 個 と有意に多く認めている.

細胞内起源に関し W-P body はゴルジ装置で合成さ れ, 分泌蛋白の輸送に関連した小器官であるといわれて いる ${ }^{28)}$ ，著者の観察でもゴルジ装置内に W-P body が 集合し，一部 cisterna と連続していると思われる像を認 めた。

W-P body はまたヒスタミンを含むことがわかって おり，物質透過性の高さを反映している小器官であると 考えられる。 また，正常血管内皮細胞には認められず， 腫瘍血管内皮細胞に有意に多く認める事実は, 非常に興 味ある点であり，透過性たけではなく，Kumar ${ }^{27)}$ が述 べているように血管新生に関与している小器官かるしれ ない.

もら一つは，TRI である。この構造物はかつて全身 性エリテマトーデス特有のものと考学られていたが，そ の後 Sjögren syndromeなどの自己免疫疾患, 間葉系拉 よび上皮系の腫瑝などにも観察され，TRI に関する報 告は枚挙に暇がない、26,29 33)。 また出現する細胞は血管内 皮細胞だけでなく, 線維芽細胞, リンパ様細胞, 腫瘍細

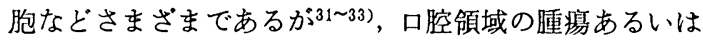
扇平上皮癌に扣ける TRI の出現の報告はない.
Landolt ら ${ }^{30)}$ による組織化学的研究で TRI が DNA を含む protein strand であることが明らかとなったが， その本質については，1. paramyxovirus と形態学的に 類似していることより virus 由来である。 2. 小胞体と 関連して存在することより小胞体の变性物である. 3. 外界の刺激に対する何らかの反応産物である。という3 つの考方方があり，いまだ明解な解答は得られていな い. 著者の観察では, 腫瘍血管内皮細胞にのみ高頻度に 認めたが，その大きさは一定していない，また粗面小胞 体と関連を有するものは半数であったことより，この小 器官の存在意義を明らかにすることは不可能である。乙 かし，自己免疫疾患にも多く認められていることは，細 胞レベルでの免度機構になんらかの関連をもっているの かもしれない。

扁平上皮癌腫瘍血管内皮細胞に TRI を高頻度に認め たことは過去に全く報告がなく，特記すべき所見である と思われる。

以上のような不連続型血管の出現, 多数の luminal process, junction の形態異常, W-P body, TRI の存在 は, Rhodin ${ }^{7)}$ が述べている真性毛細血管に続く径 $20 \mu$ 前後のいわゆるメタ細静脈に相当する細血管の血管内皮 細胞にみられ，明らかに透過性克進の所見をしめしてい る.

正常血管の真性毛細血管とメ夕細静脈は径が異なる以 外, 形態学的には明膫に区別することは不可能である が, メタ細静脈は, 炎症栄において透過性充進あるいは 白血球遊走の場となり, gap 形成などの形態变化を認め ることがわかっている3,7,34,35).

腫瘍毛細血管は細動脈，細静脈の分化は，まれとされ ているが2,11)，山浦 ${ }^{10)}$ は否定的見解をとっている。 そし て今回の観察で, 腫瘍血管に拈いても真性毛細血管と入 タ細静脈の間の形態の違いが明膫となったことは細静脈 への分化が行われたことを意味していると思われる.

しかし，以上のような特徵的所見がすべての腫演血管 にみられたといらわけではなく，腫痬血管でも何ら正常 血管と形態的に違いを見出し得ない血管も多く，過去の 


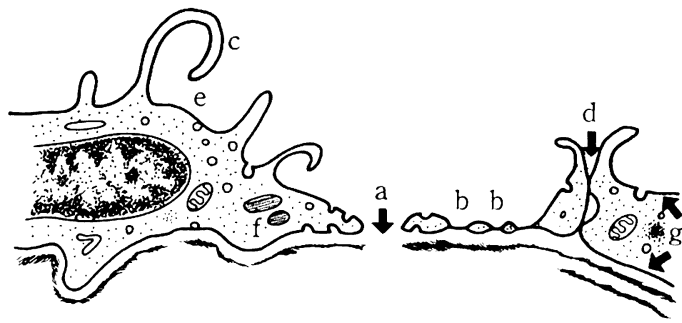

図 2 末治療腫瘍血管の超微形態と物質透過経路の 模式図

a) 不速続部 (gap) b) fenesration with piaphragm (F.D.) c) luminal process d) junction e) pinocytotic vesicle f) Weibel-Palade 顆粒 g ）細胞膜

報告にも同様の記載が多い2,8,20,36) この点に関して, 鈴木 ${ }^{2)}$, Seng ${ }^{20)}$ は, 腫瘍血管は種々の stage の血管が腫 場組織の中に混在するので形態的にも機能的にも部位に よって不均一であると述べている，腫瘍血管内皮細胞の turn over time が正常に比べ20〜2,000 倍早いとされて いることからすると ${ }^{38)}$ ，さまざまの stage の血管が混在 し，それに対応して形態が多彩であることは十分考えら れることである。

次に口腔粘膜扁平上皮癌腫瘍血管は他の悪性腫瘍腫瘍 血管と比較してどのような特徵があるのか考察を加える 必要があろ5，表 2 は過去の文献からヒトに打源発 性の悪性腫瘍腫瘍血管の超微形態特徵をまとめたもので ある ${ }^{5,8,18 \sim 22,32,37,39,40)}$ 最も特徵的な傾向は発生母組織 の血管形態に関わらず, F.D., gap が多く認められるこ とである。すなわち本来は無空性の血管をもつ原発性脳 腫瘍の腫瘍血管においても，また類洞型血管である肝臓 より発生した肝癌腫瘳血管においても基本的には形態に 差がないよらである。著者の観察結果との比較において も同様である. Hirano ら $11,22,39,41,42)$ は腫隍血管は発生 母組織の間質を模倣すると述べているが，著者はむしろ 原発部位による相違よりも<㙖湟血管>として共通の血 管形態をもっていると思われ，これらの所見はく腫瘍血 管>の特徵的所見であると考えた。

B. 尰瘍血管の透過性

前項で述べた腫渲血管壁の形態的特徵より物質輸送は 以下の経路が考えられる。その模式図を図 2 に示し，腫 痬血管の透過性を検討した。

\section{a）gap を通る輸送経路}

大きさは数千 凡にも及び隔膜，基底膜を有さず，かな り大型の物質でも通過物質の径が gap 以下であれば輸 送可能と思われる。 Horseradish Peroxidase (HPO) や ferritinを注入すると早期に gap より漏出すること がわかっており, 透過経路としては最も有効であろ $5^{8,18 \sim 22)}$. b ）F.D. を通る輸送経路

F.D. は隔膜で隔てられているものの細胞膜とは槥造 が異なり，脂質二重層ではなく，かつ柾水性基もないた め, この部を通っての透過性がかな高いことがわかっ ている13 17,34).

有空性血管が正常組織のそれより 2 倍多く認められた ことは，量的にも透過性が高いことを示していると思わ れる。

c) luminal process による物質輸送

正常血管における marginal fold と同じ取り込み様式 であり, 細胞表面積を增加させかつ辺縁血牂流の緩徐化 を起こすことにより，物質吸収の能力を高める働きが考 えられる5, 6,8, 13 15, 20,26,34)

d) junctionを通っての物質輸送

腫瘍血管では, HPO, ferritin ともに tight junction からの通過はないといわれている18) 著者の钼察結果で も部分的に細胞間開大はみられたが，必ず数か所で瘉合 しておりこの部を通っての透過性が怸進しているとは思 えなかった。しかし前述したよらに部分的細胞間開大は 血管の脆弱さを示し，昇王などにより容易に細胞間隙が 開大され，物質透過を立進せしめると思われた21)

e) pinocytotic vesicle による物質輸送

各血管扰よび各内皮細胞によって pinocytotic vesicle の分布量は異なり, 著しく数の多い内皮細胞からほとえ ど認められないものまでさまざまであった，pinocytotic vesicle による輸送経路を解明するには，立体的な定量 解析を行う必要があり, 今回の観察では明らかにするこ とはできなかった。

\section{f) W-P body による輸送経路}

この細胞小器官の機能, 特性は不明であるがヒスタミ ンを有すること，また Sengel ら 28$)$ が述べるように pinocytotic vesicle との痛合, あるいは W-P body からの vesicle の放出が事実ならば，物質輸送に関連があるの かもしれない。

g ）細胞膜による輸送経路

水, 酸素などの抬散経路として重要であるが形態的に は何ら変化を認めないため, 今回の観察では明膫にはで きず，生化学的な検索が必要であると思われる

以上のように，扁平上皮癌腫瘍血管における物質輸送 能力は正常血管に比較してはるかに大きいことがうかが われた。

また前述したように多彩な像がみられた事実は，癌 組織での血流量の不均一とも関連を有していると考え $た^{43,44)}$.

C. 血管新生

隀瘍血管の誘導因子として tumor angiogenesis factor (TAF) の存在が注目され多くの生化学的知見が得られ ているが゙，腫瘍血管がどのような過程を経て新生され， 機能するのかいまだ不明な点が少なくない、 
多くの報告者 $4,5,10,11,20,45,46)$ は，腫湟血管は宿主の微 小循環系の血管内皮の出芽によってつくられると述べて いる。一方，胎生期血管の新生と同じく未分化間葉系細 胞が集合し，血管の原型を作るとする報告もある3,47)

著者の観察では, 内皮細胞の分裂所見は全く認められ ず，血管芽の所見も明らかではなかったが，毛細血管の なかでもごく小さな血管（外径 $4 \mu$ 以内）に批いては， 管腔が著しく狭小で内皮細胞は厚く立方形をなし，電子 密度が低く細胞小器官をほとんど有していなかった。 たこの血管の周囲には多数の間葉系細胞がシート状に集 合しているという所見を得た。

Port $5^{48)}$ は，この電子密度の低い内皮細胞を新生血 管とみなしている。 また初期の幼若な血管はほとんと透 過性がみられないといら報告10,47)を考市わわせるとこ の径の小さな血管は新生血管の幼若な形態を示している のかもしれない、また，血管新生は宿主側の内皮細胞か らの出芽か，間葉系細胞の分化によるものかを明確にし 得なかったが，血管新生において血管周囲の多数の間葉 系細胞がなんらかの役割りを果たしているのであろう.

\section{2. 治療後腫瘍血管}

前章では董瘍血管は明らかに物質透過性が高い特徵を 呈し，腫㿑実質細胞の增殖にとって，またその反面治療 上でも都合のよい形態を有しているよらに思われた。し かし，治療によって腫瘍血管がどのような影響を受けて いるかについて, 超微形態学的な報告は非常に少ない.

そこで前章に批いて明らかとなった治療前腫瘍血管の特 徵と比較することにより, 治療後の血管の超微形態的変 化を追求した。

生活癌細胞残存部血管の 1 群と, 变性癌細胞塊内血管 の 2 群および般痕組織内血管の 3 群では形態学的に著し い差異を呈していた。このらち，2，3 群の内皮紐胞所 見はWeber $5^{49}$ の観察した般痕組織内の血管形態と一 致していたことより組織修復過程の血管形態を意味し， 治療の血管に対する影響を示す像としては不適当である と考えた。また 1 群のなかには，治療前腫瘁血管と同一 の所見があった。すなわち luminal process, junction の 開大所見, 内皮細胞壊死を伴わない gap 形成, TRI, W-P body の出現である。松村50) の報告にも luminal process, W-P body, 細胞小器官の增加が, 内皮細胞壊 死とともにみられ，これらは regenerative change でと もに透過性克進を示していると述べている。しかし著者 の観察では, 变性のほとんどない癌細胞のごく近辺にこ のような所見が多くみられたことから，治療による影響 を受けていない腫演血管の形態であると考えた方が妥当 であろら。そこで以下は，治療前にはみられず，治療後 に新たに出現した所見について検討を加える。

著者の钼察では, 核の形態不整, ライソゾームの出 現, マイクロフィラメントの增加, 内皮細胞の壊死, gap 形成, 血小板の凝集, 血管壁の破壊が治療前腫瘍血管と
は異なる所見として捉えられた。

これらは細静脈での所見であり，毛細血管では核の不 整, 核小体の腫大といら核のみの変化で細胞質には変化 は認めなかった。治療前腫瘍血管では毛細血管と細静脈 の明らかな形態差異を認めたことより，そもそも放射 線，BLM に対する反応が異なるためか，あるいは細静 脈は機能が亢進している部であるため, 治療による血流 の影響を受けやすく变性を起こすのかは，さらに検討の 必要があると考える。また，一般に毛細血管は感受性が 高いといわれているが50 55)，これは細静脈を含む毛細血 管床と解釈すべきであろら。

前述したように毛細血管は，放射線感受性が高く早期 障害だけでなく晚期障害の発生原因としても注目されて

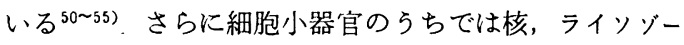
ムが共に放射線照射に対して感受性の高い標的であり， 放射線照射による細胞の影響は核の形態異常とラインジ 一ムの出現として観察されるといわれている到 58). 著者 は $1.5 \mathrm{~Gy} 2$ 回照射後にすでに内皮細胞の核の不整, ラ イソゾームの出現を認めたことより，これらの所見は放 射線の内皮細胞に対する早期障害を表していると思われ る.

また BLM は核と細胞質の退行性変化を起こすといわ れているが59), 内皮細胞に関しては内皮細胞の腫大によ る血管腔の狭小化, 空胞形成, 血栓形成, 壊死の記载の みである ${ }^{61 \sim 4)}$ ，乙かし壊死が認められるならば，核の不 整, ライソゾームの出現も壊死に移行しらる形態変化と して子測可能な所見であり, 併用療法に扣ける核の不 整, ライソゾームの出現に BLM の影響が全くなかった とは断定しえないであろう.

内皮細胞の変性とならんで治療後にみられた最も大き な变化は内皮細胞の壊死である。放射線単独照射，およ び BLM のみの投与においても内皮細胞の壊死について の報告があるが50,55,62,65)，著者の観察結果は松村 $5^{50,55)}$ の人脳の遅発性放射線壊死に打ける血管病変の所見と酷 似していた。すすなわ壊死内皮細胞は電子密度がやや高 く, 細胞質が菲薄で, 細胞小器官はほとんど認められ す，これらの変性物と思われる空胞が多数見られた。

内皮細胞の壊死性変化について馬場は年), ライソゾー ムの增殖はやがてオートファゴライソゾームに進展し, ついで細胞変性，さらに壊死に陷ると記述している．著 者の観察でる初期には内皮細胞の壊死はみられず，治療 後に多数のライソゾーム,オートファゴライソゾームむ みられたことより前述した核の不整, ライムゾームの出 現といら早期細胞障害から進展し内皮細胞の壊死がた らされたと推測される。

このよらな壊死性変化を呈している内皮細胞には, 必 ずF.D. と gap が認められた。 F.D. と gap の形成に ついて,もともとこれらを有していた内皮細胞が壊死に 陥ったのか, 壞死に陥って形成されたのかは明瞭でない 

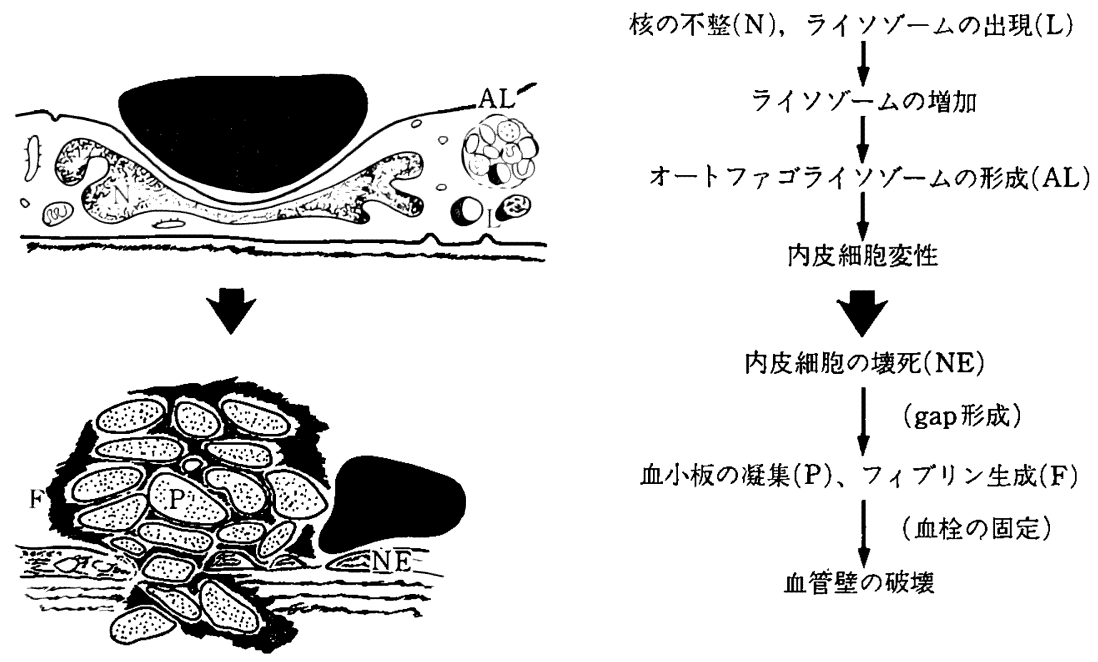

内皮細胞の壊死(NE)

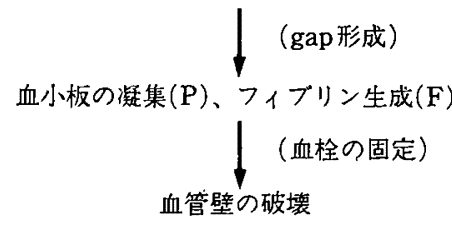

図 3 放射線, BLM 併用療法による腫汪血管の形態変化

が, 治療前例, 治療例とも同一血管に F.D. と gap が みられたことは，前項で述べたように F.D. と gap の 形成機序には関連があると思われる ${ }^{18,23,55,56)}$.

さらに内皮細胞の壊死性変化が強い血管では，血管周 囲を同心円状に取り囲んでいる基底膜が特徵的所見であ った，松村 ${ }^{50,55)}$ は，これは基底膜の損傷を表し，透過性 を高めていると述べている，またVracko ら ${ }^{66)}$ は，毛細 血管の壊死，再生の絽り返しによる結果だとしている. いずれにせよ基底膜の多層化は血管の障害を表す所見と

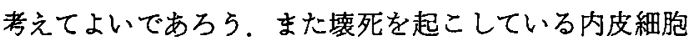
の gap 部には, 血小板の凝集が認められた。これは内 皮細胞か゚欠損する部は血液と血管周囲腔との間の抵抗が きわめて脆弱になっており，両者の交通が激しく行われ た結果, 血漿成分が量を減じ蛋白の凝集, 循環細胞成分 の凝集を引き起こし血栓を形成するためと考兄られる. Ashford ${ }^{67)}$ は, 結合織が露出され組織トロンボプラスチ ンと接触した時にのみ血小板凝集が起こり, その祭の血 小板の変性, フィブリン形成は血栓を安定化させると述 ベている68).

このよらな血栓の固定化と血管腔の閉塞は内皮細胞の 不可逆性の変化を導く。すなわち壤死内皮細胞よりなる 血管腔には変性血小板, フィブリンが凝集, 閉塞し，さ らにこれらが gap を通って周囲結合織にまで広く集積 することにより，血管壁は完全に断裂，破壊される ${ }^{67,68)}$. そして，それは著者の観察であ認められたことである.

以上のことより放射線, BLM 併用療法は重瘍実質細 胞のみではなく，血管内皮細胞にも障害を与えることが 明らかとなった。すなわち最も初期の変化は核の不整, ライソゾームの出現であり，さらにライソゾームが増 殖, オートファゴライソゾームも形成され内皮細胞は壊
死に陥る。そして壊死内皮細胞に生じた F.D. 拈よび gap により血管の透過性が増大し，血栓を形成する。 た血小板の変性, フィブリンの析出により血栓は成長, 安定化しついには血管壁の破壊を生じるすのと推測され る. その過程を図了に示す.

これらの血管障害に対し，放射線，BLM のいずれが より強い影響を及ぼすかに関しては，今回の観察では明 らかにできなかった。

ここで，これらの血管障害の所見が果たして治療に対 し有効であるか否かという問題が臨床の場においては重 要となってくる，これに関しては相反する 2 つ考方方 がある.すなわち Denekamp ${ }^{38)}$, Hagedorn ${ }^{61)}$ は血管の 閉塞が腫瘍細胞の壊死をもたらすとし抗腫瘍効果を上げ ると述べている，また全く逆に Burkhad ${ }^{62)}$ は，血管閉 塞に続く血管消失は臨床上治療効果は得られなかったと 述べまた Rubin ${ }^{1)} は$ 血管障害は supervascularization を抑制することによりともに，治療上好ましくないと述 ベている.

これに関して著者は，治療開始後ごく早期に核の不 整, ライソゾームの出現などの退行性変化がみられたこ とより腫瘍血管に拈ける物質透過性は低下しており，そ のために酸素供給, 抗癌阂到達路としての血管機能の障 害が起こってくると考えた。

さらに破壊された血管の周囲にな和生活癌細胞が残存 しているといら事実は，血管閉塞による栄養血管杜絶を 図り，腫瘍細胞を壊死に陥らせるためにはさらに中权 側, あるいは多くの周囲栄養血管の閉塞が必要であると 考えられる、すなわち積極的な治療としての局所の栄養 血管を狙った clumping などの方法でなければ治療効果 は期待できないと思われる。 
以上の理由より放射線，BLM 併用療法における血管 障害は，血管機能の低下および血管消失を招き，治療効 果の上では，好ましくないと思われた。

結論

ヒトロ腔粘膜扁平上皮癌腫瘍血管の形態学的特徵を明 らかにするため，正常口腔粘膜血管，治療前および放射 線, BLM 併用治療後の腫瘍血管について透過型電子顕 微鏡を用いて観察を行い，以下の結論を得た。

1. 正常口腔粘膜血管は有空性, 無空性の 2 型であり, 正常舌䇨部血管は無空性のみであった。

2. 治療前腫瘍血管

1) 外径 $4 \mu$ 以下の小さな毛細血管の内皮細胞は細胞 小器官が少なく, 電子密度が低い。これらは新生幼若血 管と思われ，周囲に多数認められた間葉系細胞は血管新 生に関与していると推測された。

2 ) 直径 $20 \mu$ 前後のいわゆるメ夕細静脈に相当する 血管においては，不連続型血管を認め，内皮細胞では junction の形態異常, 多数の luminal process を観察し た。また特異な細胞小器官として Weibel-Palade 顆粒, tubuloreticular inclusions を内皮細胞に認めた。 また舌 筋内に腫瘍が浸潤している部の尰瘍血管には有空性血管 を認め，有空性血管も腫瘍血管の一形態であると考え た。また有空性血管の存在率は正常粘膜血管の 2 倍であ った。これらの所見は, 内皮細胞の透過性六進の高さを 示す像であり，腫瘍血管は正常血管に比較して物質輸送 能力が高いことが明らかとなった。

3. 治療後腫瘍血管

放射線, BLM 併用治療後の血管内皮細胞は核の不整, ライソゾームの出現, マイクロフィラメントの明瞭化, さらに壊死，血小板凝集，血管壁の破壊などの血管障害 を認め, これらの変貌は早期より起こり, 血管透過性を 低下させ，最終的には血管消失を招くため, 治療上好ま しくないと考えた。

稿を終えるにあたり，終始こ想篤なるこ指導とこ校閲 を晹わりました本教空主任田代英雄教授に, 䔆んで感謝 の意を表します。またこ協力を頂きました本学口腔外科 第 2 䛶座, 扩よび当教窒の諸先生方に心よりお礼申し上 げます。

本論文の要旨は, 第37回日本口腔科学会総会（大阪, 1983)，第 28 回日本口腔外科学会総会（東京，1983）拧 よび第 9 回日本頭頸部腫痬学会（東京，1985）に扣いて 発表した。

\section{引 用 文 献}

1) Rubin, P. and Casarett, G.: Microcirculation of tumors. part II ; The supervascularized state of irradiated regressing tumors. Clin Radiol 17: 346-355 1966

2) 鈴木磨郎：腫演血管の機能的特異性一昇圧化学 療法の基礎として。抗斫誌 36：94-104 1985.

3) 東 健彦, 土屋雅春, 他編：媺小循環。第 1 版, 中山書店, 東京, 1979, 125-151頁.

4) Folkman, J.: Tumor angiogenesis factor. Cancer Res 34: 2109-2111 1974.

5）松鵈典彦：実験的舌癌における血管構筑ならび に腫璄血管の超微構造. 日口外誌 28：175-191 1982.

6) 小林光道: DMBA 誘発ハムスタ一舌癌に対す る放射線効果の研究。菌学 68: 700-733 1980 .

7) Rhodin, J.A.: Ultrastructure of mammalian venules and small collecting veins. J Ultrastruc Res 25: 452-500 1966.

8) Long, D.M.: Capillary ultrastructure and the blood brain barrier in human malignant brain tumors. J Neurosurg 32: 127-144 1970.

9）大星章一,下里幸雄, 他: 癌放射線の病理。医 学のあゆみ 61：618-671 1977.

10）山浦玄嗣：腫湯血管の形態と機能に関する実験 的研究. 抗研誌 23: 100-119 1971.

11）鈴木磨郎，阿部郁夫，他：血管新生特に腫痬血 管形成について。抗矿誌 37: 88-92 1985.

12) Bennet, H.S., Luft, J.H., et al.. Morphological classification of vertebrae. Am J Physiol 196: 381-390 1959.

13）藤本萡, 竹重順夫：血管内皮の構造と機能. 細胞 4：2-16 1972.

14）山田英智：血管内皮の構造と機能。血液と脈管 3: 511-521 1972.

15）猪口哲夫, 村上正浩: 毛細血管の超微構造. 細 胞 13: 429-436 1981.

16）山元寅男：毛細血管透過の形態学. 日本臨床 41: 184-195 1983.

17）高橋常男：㳡肉内縁上皮下の有告性血管に関す る電顕的微察。神奈川米学 13：113-133 1978.

18）过本守孝：Vx 2 腫瘳内血管に打ける外因性 peroxidase および ferritinの透過性に関与る電 顕的・細胞化学的研究. 日口外誌 28:341-359 1982.

19) Vick, N.A. and Bigner, D.D.: Microvascular abnormalities in virally induced canine brain tumors: Structural bases for altered bloodbrain barrier function. J Neurol Sci 17: 29391972.

20) Papadimitriou, J.M. and Woods, A.E.: Structural and functional characteristic of the microcirculation in neoplasmas. J Pathol 116: 
65-72 1975.

21) Seng, A.E.: 肺癌毛細血管の電子顕微鏡学的研 究. 抗砳誌 25：214-231 1973.

22) Long, D.M.: Capillary ultrastructure in human matastatic brain tumors. J Neurosurg 51: 53-58 1979.

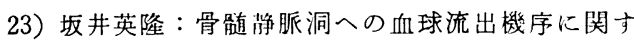
万電子顕微鏡的检索一顆粒球系細胞に関して。 九血会誌 29: 49-82 1981 .

24) Seng, A.E., Neyazaki, T., et al.. Unusual intraluminal processes of capillaries in a case of undifferentiated lung cancer. Tohoku J Exp Med 110: 1-5 1973.

25) Weibel, E.R. and Palade, G.E.: New cytoplasmic components in arterial endothelia. J Cell Biol 23: 101-112 1964.

26) Hirano, A. and Matui, T.: Vascular structures in brain tumors. Hum Pathol 6: 611-621 1975.

27) Kumar, P., Kumar, S., et al.: Weibel-Palade bodies in endothelial cell as a marker for angiogenesis in brain tumors. Cancer Res 40: 2010-2019 1980.

28) Sengel, A. and Stoebner, P.: Golgi origin of tubular inclusions in endothelial cells. J Cell Biol 44: 223-227 1970.

29) Henderson, D.W. and Papadimitriou, J.M.: Ultrastructural Appearances of Tumors. 11 th Ed, Churchill Livingstone, Edinburgh, London, Melbourne and New York, 1982, p 43-55.

30) Landolt, A.M., Ryffel, U., et al.: Ultrastructure of tubular inclusions in endothelial cells of pituitary tumors associated with acromegary. Virchows Arch Pathol Anat 370: 129-140 1976.

31) Gyorkey, F., Sinkovicks, J.G., et al.: Electron microscopic observations on structures resembling myxovirus in human sarcomas. Cancer 27: 1449-1454 1971.

32）森園隆昭：翏原病に打ける腎毛細血管内皮細胞 内管状網状構造物 (TRS) 一その意義および origin. 臨床電顕誌 12: 65-80 1979.

33) Uzman, B.G., Saito, H., et al.: Tubular arays in the endoplasmic reticulum in human tumor cells. Lab Invest 24: 492-498 1971.

34) 田崎政, 吉永秀, 他: 血管透過機構一その 形態学々生化学。㔻核醉 14：1336-1350 1969.

35) 山口寿夫, 竹内広, 他: 炎症時の血管内皮. 血液之脈管 3：53-60 1971.

36) 羞豊：ラット脳腫場に打ける血液脳関門の 障害について 一horseradish peroxidaseを用い た電顕的研究. 長崎医会誌 58：98-116 1983.

37) 班目健夫：実験的肝細胞癌の走查電顕による钼 察。岩手医誌 36：207-210 1985.

38) Denekamp, J.: Vascular endothelium as the vulnerable element in tumors. Acta Radiol
Oncol 23: 217-225 1984.

39) Ward, J.D., Hadfield, M. et al.: Endothelial fenestrations and other vascular alterations in primary melanoma of the central nervous system. Cancer 34: 1982-1991 1974.

40) Lundatscher, R.M., Gallei, B., et al.: Ultrastructural observations of human thyroid tumours. J Pathol 128: 57-62 1978.

41) Hirano, A. and Zimmerman, H.M.: Fenestrated blood vessles in a metastatic carcinoma in the brain. Lab Invest 26: 465-468 1972.

42）鉿木磨郎，堀勝義：血管内皮細胞と血管增 殖。生体の科学 36: 207-210 1985.

43) Vogel, A.W.: Intratumoral vascular changes with increased size of mammary adenocarcinoma-new method and result. J Natl Cancer Inst 34: 571-578 1965.

44）原田康：腫瘍血流動態に関寸る研究. 日医放 会誌 33：740-755 1973.

45) Rubin, P. and Casarett, G.: Microcirculation of tumors Part II ; Anatomy, function and necrosis. Clin Radiol 17: 220-229 1966.

46) Ausprunk, D.H. and Folkman, J.: Migration and proliferation of endothelial cells in preformed and newly formed blood vessels during tumor angiogenesis. Microvasc Res 14: 53-65 1977.

47）泰 順一，玉置雪一，他：腫湟血管新生に関寸 万形態学的研究. 最新医学 36: 1841-1845 1981.

48) Port, C.D. and Ward, W.F.. The ultrastructure of radiation injury in rat lung; modification by D-penicillamine. Radiat Res 92: 61-82 1982 .

49) Weber, K. and Braun-Falco, O.: Ultrastructure of blood vessels in human granulation tissue. Arch Dermatol Res 248: 29-44 1973.

50) 松村豪一：人脳の遅発性放射線壊死の血管病変 とその発生機序。臨床電顕誌 14：1-23 1981.

51）佐伯祐志，小川史顕，他：実験腫瘍の微紐血管 分布に対する放射線の影響。日医放会誌 35 : 158-167 1975 .

52) 佐伯祐志：腫㿉血管に対子る放射線の影響に関 する研究。京付医大誌 83：423-433 1974.

53）河村文夫, 藤原寿則, 他：照射に上る谈小循環 系の障害。細胞 7：548-558 1975.

54）田中敬正：局所腫瘍血流状態之故射線感受性. 日医放会誌 32：425-434 1972 .

55）松村豪一, 平野朝雄：人脳の遅発性放射線壊死 に扣计万微小血管; 内皮細胞構築に関する知 見. 臨床電顕誌 9：37-43 1976.

56) Casarett, G.W.: Radiation Histopathology vol. 1. 1 st Ed, CRC press, Florida, 1980, p 1-106.

57) Maisin, J.R., Reyrers, H., et al.: Changes in the ultrastructure and the permeability of the capillaries after irradiation. Bibl Anat 15: 
311-314 1977.

58）藤本知一：ラット蒾肧細胞に対する放射線炤射 の影響について。㐘故 21: 67-83 1981.

59）山根源之：抗癌物質の作用機序に関する電子顕 微鏡的砳究. 料科学報 74:83-108, 241-276 1974.

60）馬場恶臣：正常孚腺ならびに孚腺の良性および 悪性腫埸の電子顕媺鏡的観察。臨床電顕誌 6: 141-168 1973.

61) Hagedorn, H., Petres, J., et al.. Bleomycin Tumorzell-veranderungen und Gefawirkungen beim Patienten. Arch Dermatol Res 250: 71801974.

62) Burkhadt, A., Holte, W.J., et al.: Vascular lesions following perfusion with bleomycin -electron microscopic observation. Virchows Arch Pathol Anat 372: 227-236 1976.

63）西下 明，木村郁郎，他：腫瘍扰よび肺の血管
に扰よぼすBleomycinの影響、脈管学 11:23261971.

64）木村郁郎, 大歇泰亮, 他 : Bleomycin による悪 性腫瘍の治療に関する研究（第 3 報）一血管系 に及ほすす影豐について一(抄). 日癌学会総会記 事 (第29会総会) 2521970.

65) Kahn, M.Y.: Radiation-induced changes in skeletal muscle-an electron microscopic study. Am J Pathol 73: 131-146 1973.

66) Vracko, R., Benditt, E.P., et al.: Capillary basal lamina thickening. J Cell Biol 47: 2812851970.

67) Ashford, T.P. and Freiman, D.G.: The role of the endothelium in the initial phases of thrombosis-an lectron microscopic study. Am J Pathol 50: 257-273 1967.

68）福武勝博, 安井武義, 他: 消費性凝血異常の病 態生理。血液と脈管 1：53-63 1970. 


\section{写 真 説 明}

写真 1 正常血管 $(\times 6,300)$

正常䧒肉に扣ける毛細血管を示寸。1 個の内皮細胞 ( $\mathrm{E})$ と基底膜 (BM)，周皮細胞 ( $\mathrm{P}$ ) よりなる。

写真 2 正常血管 $(\times 6,100)$

舌筋層内の毛細血管を示す。多くの vacuole と pinocytotic vesicle がみられる。基底膜 (BM) は肥厚している。

写真 3 治療前腫瘦血管 $(\times 6,970)$

毛細血管（c）の内皮細胞は， plump な形態ななし，細胞小器官が少㭘く電子密度分低 い. 周困には多数の線維芽細胞 ( F ) が認的られる。

写真 4 治療前腫痬血管 $(\times 4,320)$

毛細血管（c）の周囲には多数の間葉系紐胞がシート状に密に配列している。

写真 5 治療前腫瘍血管 $(\times 9,800)$

血管腔内（L）に多くの luminal process を認める。

写真 6 治療前腫鹊血管 $(\times 18,500)$

長さ $2 \mu$ に及ぶ luminal process 内にはF.D. (失印) が認められ，あたかも vacuoleを 形成しているよ5にみ兄る。

写真 7 治療前腫瘍血管 $(\times 35,400)$

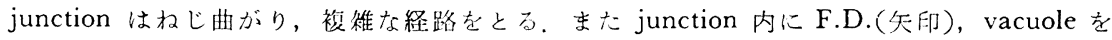
多く認める。

写真 8 治療前腫瘍血管 $(\times 47,100)$

junctional structure は2 力所（矢印）に認められるが，隣接内皮細胞間は非常に払大して いる.

写真 9 治療前腫序 血管 $(\times 26,200)$

核周辺部のゴルジ装置内に多数の W-P body（矢印）を認める。

写真10 治療前腫瘲血管 $(\times 49,700)$

非常に払張した粗面小胞体内に認められた TRI を示吉.

写真11 治療前腫瘍血管 $(\times 18,000)$

2 つの TRI (矢印) が粗面小胞体とは関連なく存在している。

写真12 治療前腫瘍血管 $(\times 20,930)$

junction 近浐に gap (矢印) を認める。

写真13 治療前腫瘍血管 $(\times 37,060)$

gap 部 (矢印) で内皮細胞の細胞質の一部が血管腔 (Lu) に翻転している。Pは周皮紐胞 を示与。

写真14 治療後腫瘍血管 $(\times 11,000)$

核（N）は砂時計様の形態を呈し，いびつとなっている，血管腔内には赤血球 (Er)が認 められる。

写真15 治療後腫瘍血管 $(\times 5,500)$

核の形態は不整で，切れこみが顕著で古る。

写真16 治療後腫瘲血管: $(\times 30,100)$

マイクロフィラメントが細胞小器官の間を縫５よにに走行している。

写真17 治療後腫瘍血管 $(\times 17,500)$

さまさまな形態のラインゾーム（失印）を示す。

写真18 治療後腫瘍血管 $(\times 24,350)$

核周辺に巨大なオートファゴライソゾームを認める。

写真19 治療後腫瘍 血管 $(\times 3,320)$

内皮細胞は菲薄で，壊死性変化を呈している。gap（大知印）と F.D. (小知印) は必ず同 一血管内に認められる。立基底膜 (BM) は多層である。

写真20 治療後腫瘍血管 $(\times 19,100)$

内皮細胞（E）は壊死性変化を呈し，断裂している．F.D.（矢印）も㢹められる，血管腔 内には変性した血小板（P）扣よびフィブリンが充満している. 

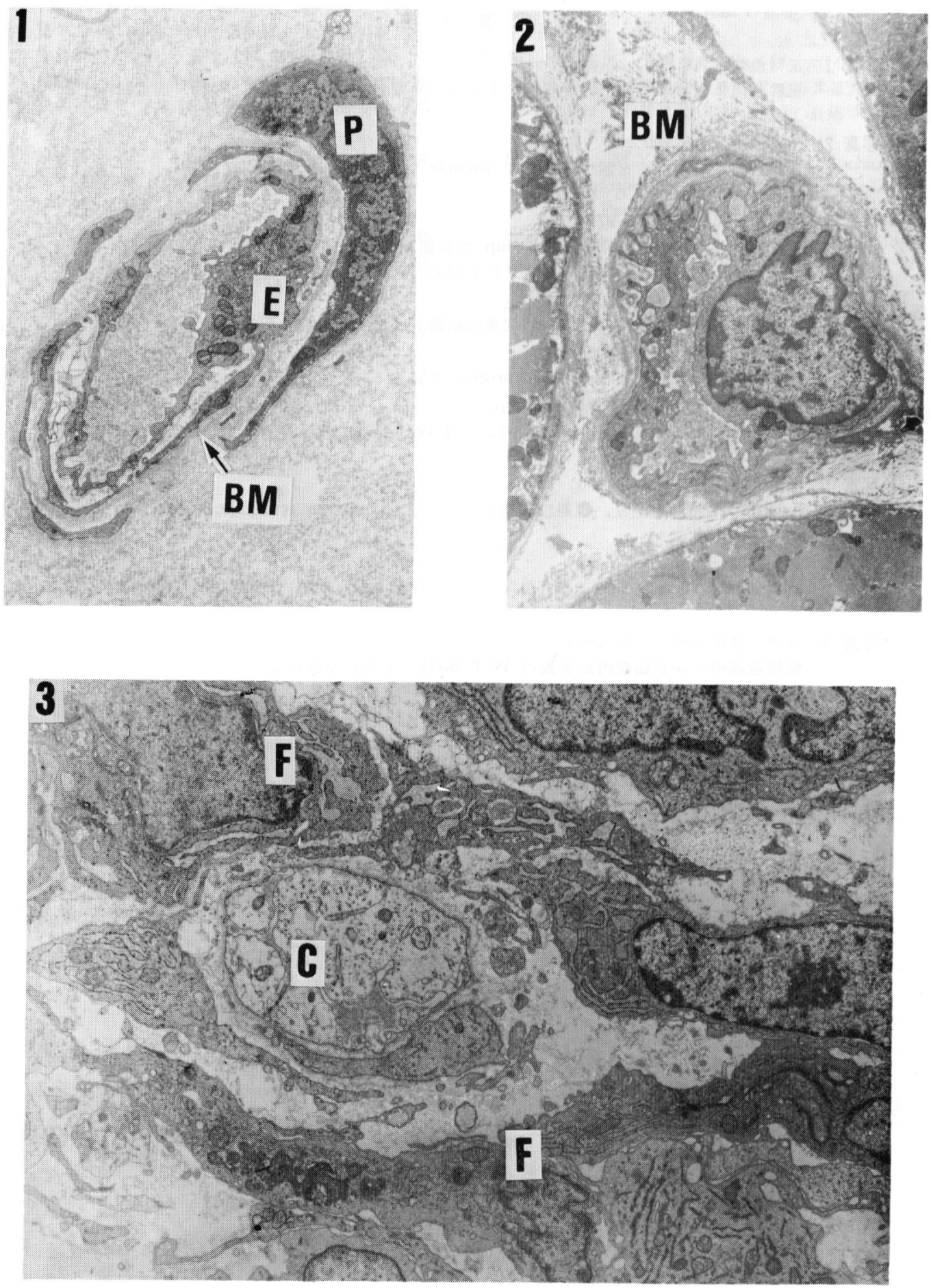

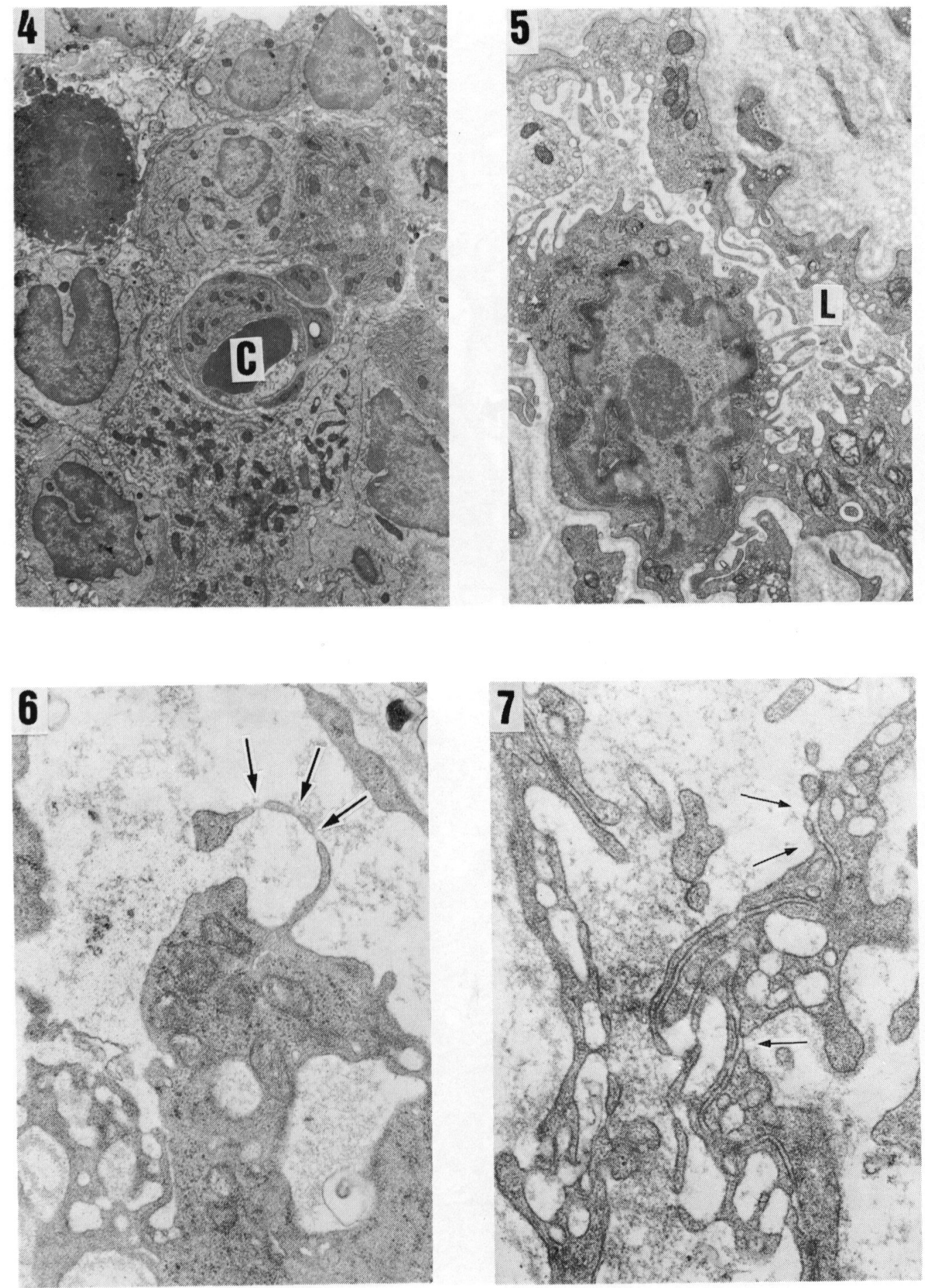

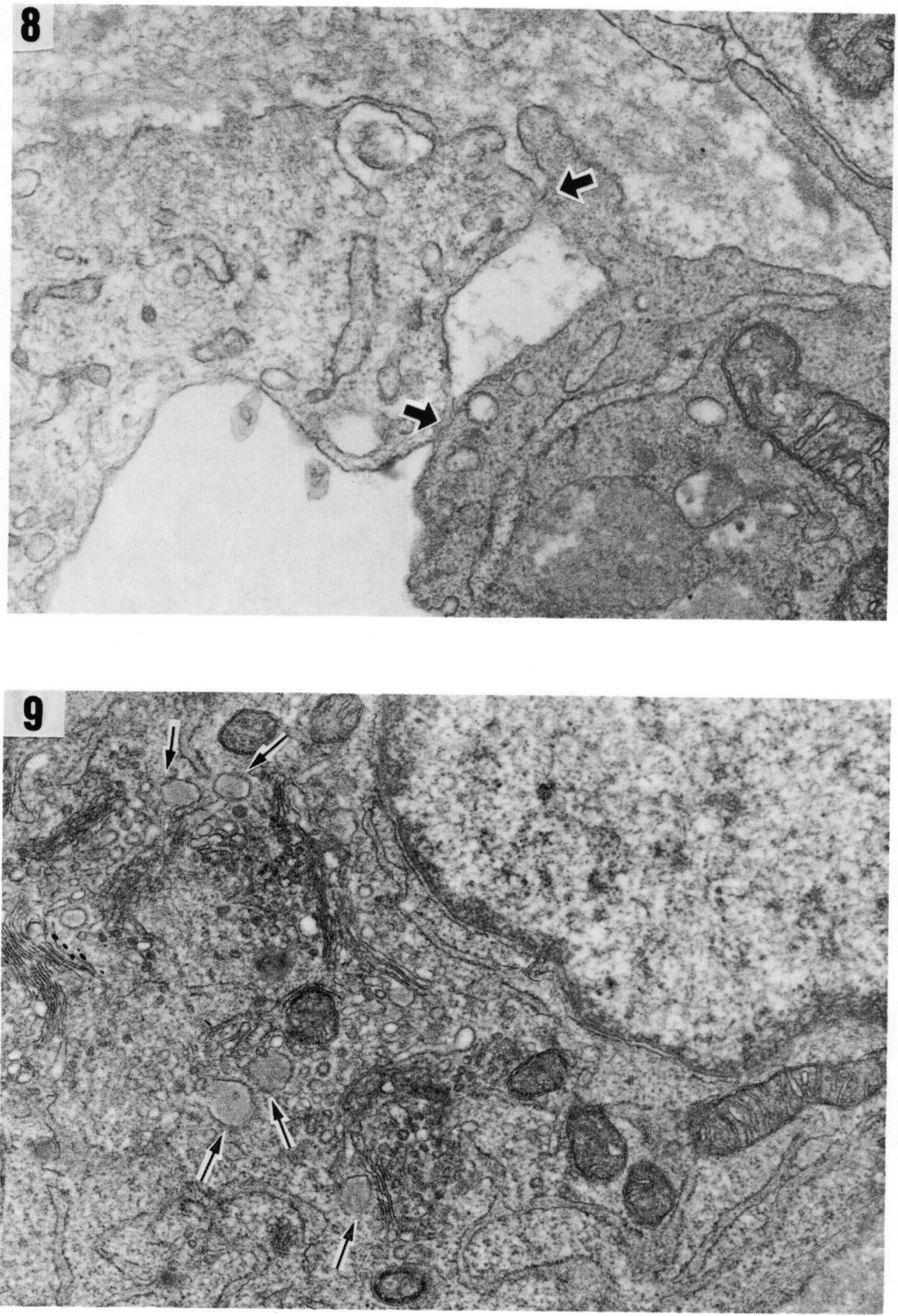

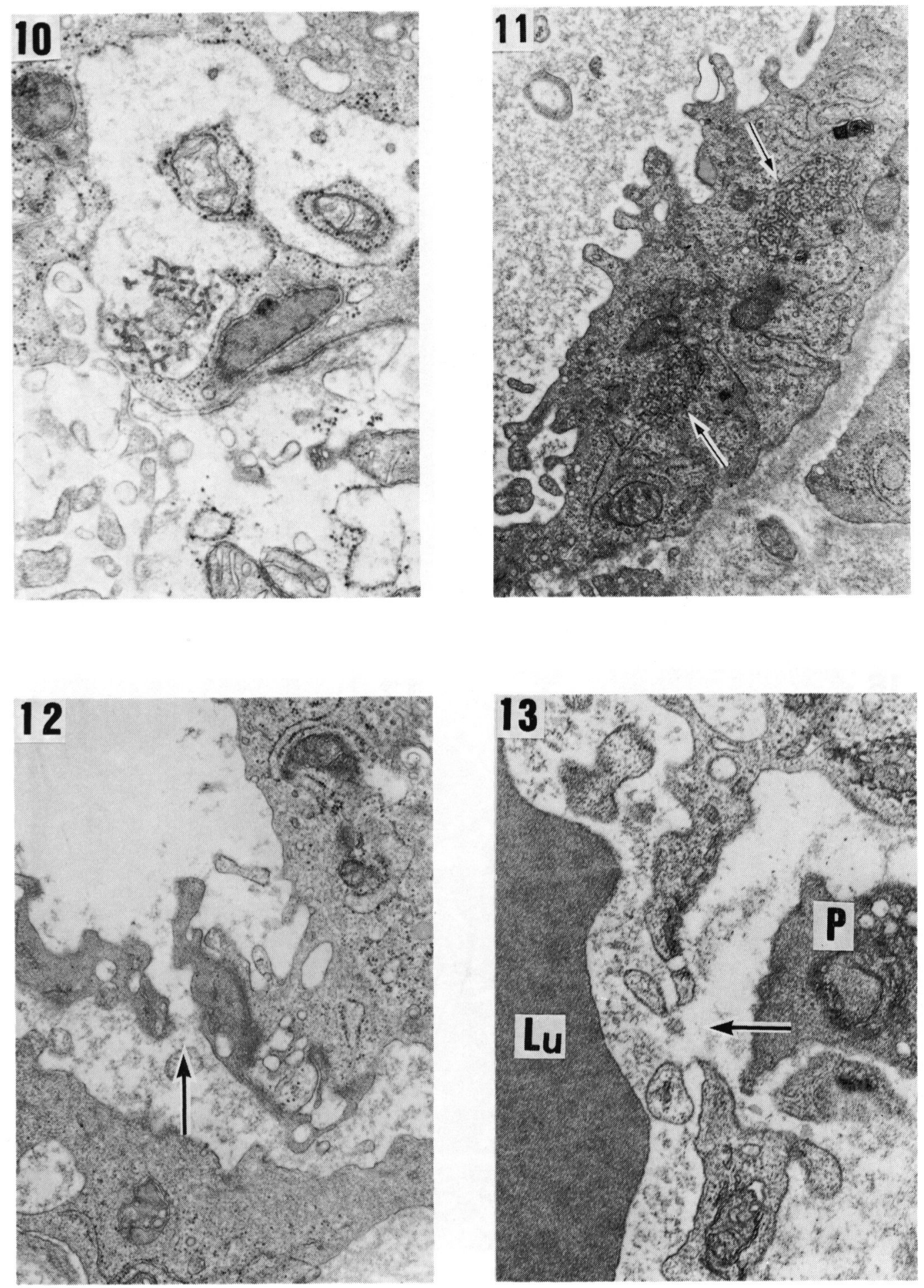

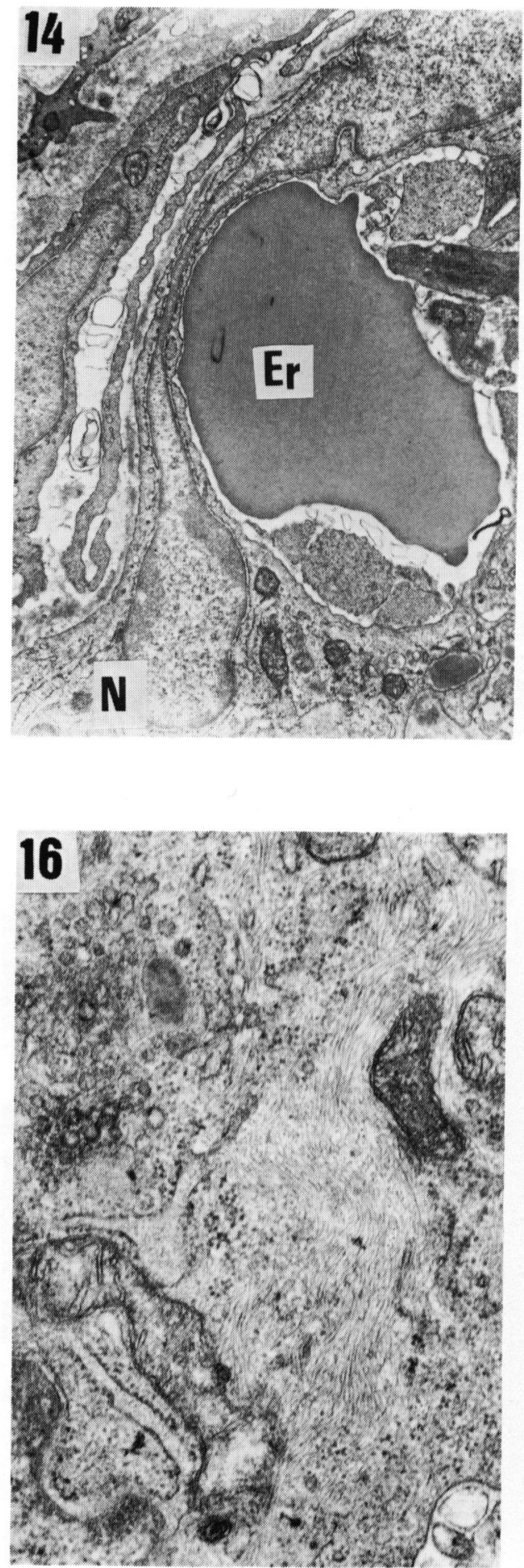
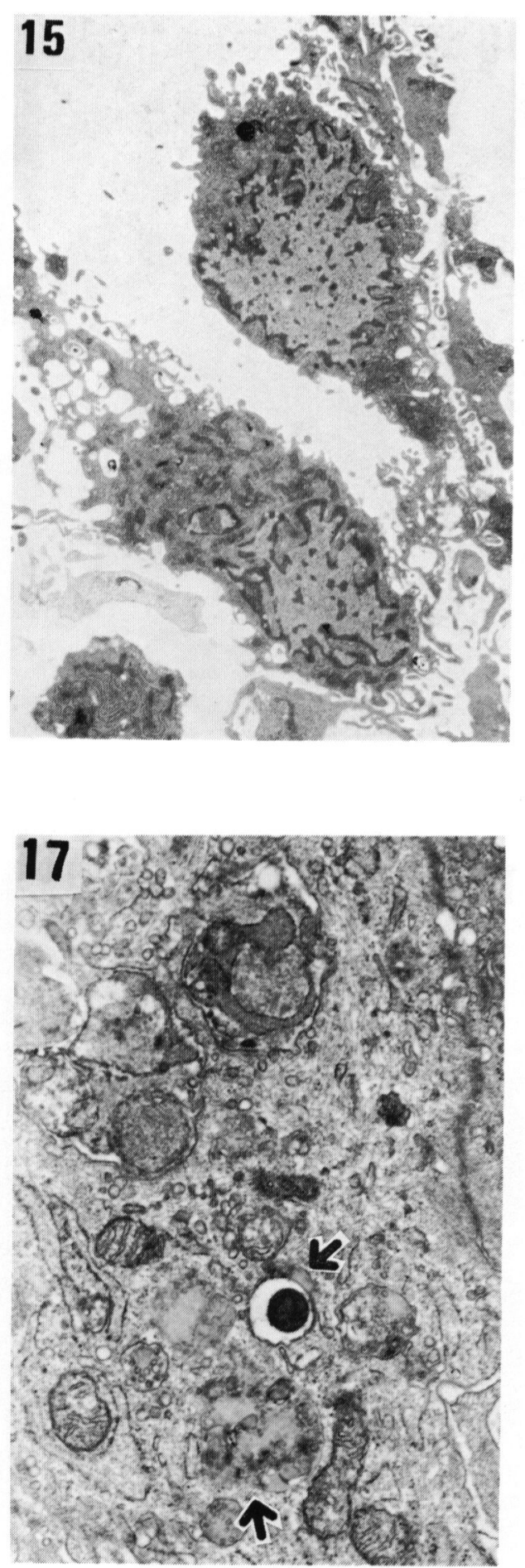

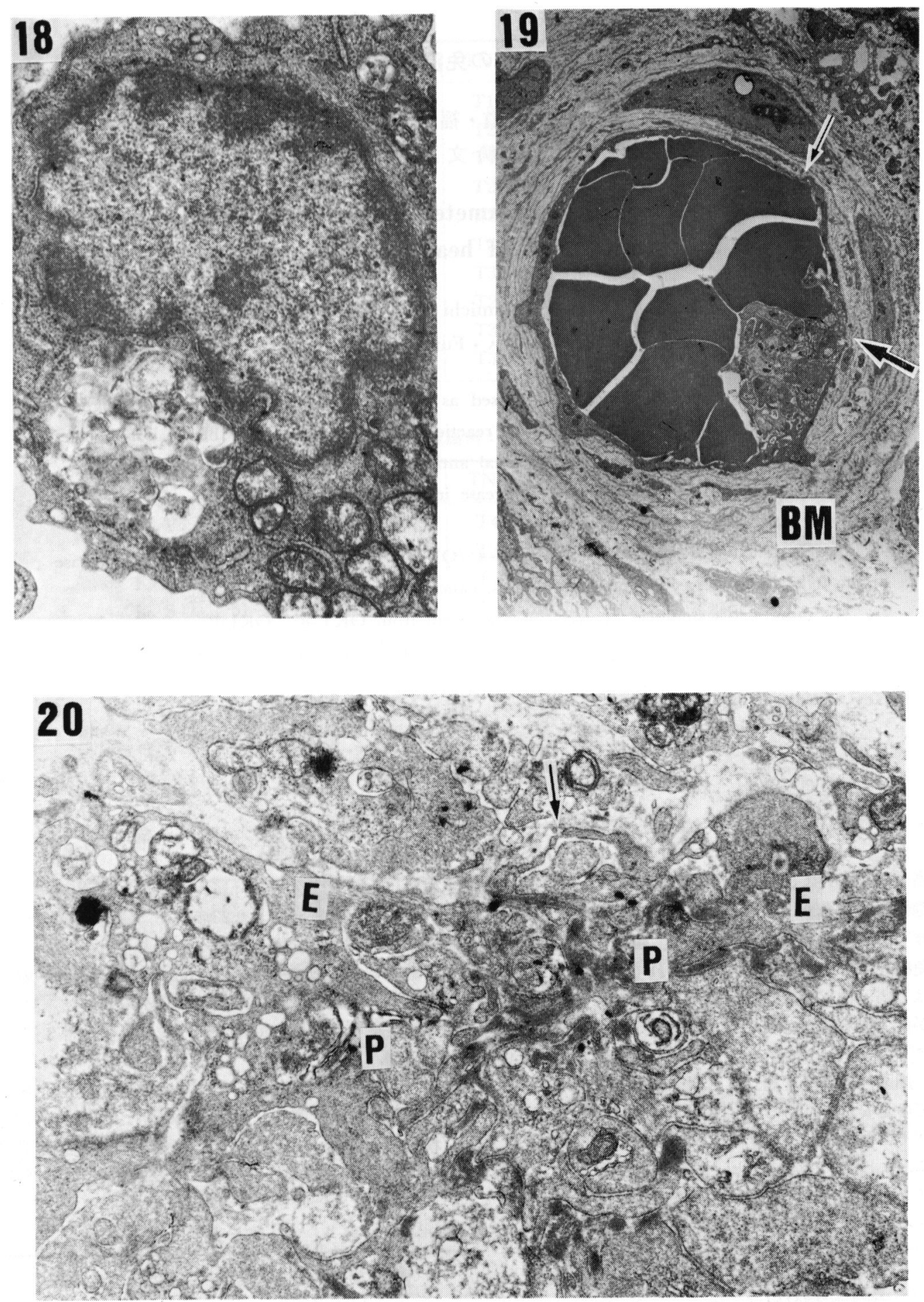